\title{
EXPERIMENTAL PERFORMANCE OF FLEXURAL CREEP BEHAVIOR OF FERROCEMENT SLAB
}

\author{
Sidramappa Dharane ${ }^{1}$, Archita Malge ${ }^{2}$ \\ ${ }^{I}$ Assistant Professor, Department of Civil Engineering, SVERI'S College of Engineering Pandharpur, Maharashtra, India \\ ${ }^{2}$ Assistant Professor, Department of Mathematics, SVERI'S College of Engineering Pandharpur, Maharashtra, India
}

\begin{abstract}
Experimental flexural creep behavior of ferrocement slab and RCC slab was studied. Fourteen slab panels were casted and tested. The first cracking load and collapse load along with the deflections were measured during the test for every increment of gradual load. The gradual load was kept constant for 24 hours and the deflections were measured at 0, 1, 3, 6, 9, 12, 24 hours for each increment of load. It was found that the first cracking load depends upon the specific surface of the reinforcement. Also the behavior of ferrocement slab found to be more ductile as compared to RCC slab designed for same moment of resistance. The theoretical moment of resistance by using IS method and Hongestad's method was found and the results were compared with RCC slab. The efficiency ratios at cracking and collapse were found. The flexural creep behavior of ferrocement slabs were found superior to RCC slab.
\end{abstract}

Keywords:-Ferrocement, RCC, slab, gradual loading, flexural creep behavior etc. ****

\section{INTRODUCTION}

\subsection{General}

Concrete has been accepted as a material of structural construction. However, it has two main disadvantages Viz., low tensile strength and poor ductility. These difficulties have been overcome by providing steel in tension zone, such concrete being called reinforced concrete. Minimum cover and minimum thickness requirement of reinforced concrete structures results in high self weight Thereby most of the load carrying capacity of reinforced concrete section goes to resist the effect of the self-weight of the member itself. Steel provided in tension zone (for low percentage) and compression zones of concrete improve strength and ductility. The beneficial influence of large deformable capacity of steel is on concrete totally. Hence, reinforced concrete is treated as one phase material. The assumption made in the design of reinforced concrete section that perfect bond exists between concrete and steel is very realistic. The concrete surrounding the steel deform under the load. When compared to concrete, steel can undergo large strains. Hence concrete in the immediate neighborhood of steel can also undergo large strains due to bond between steel and concrete. If the reinforcement is subdivided and distributed evenly, especially small diameter bars at closer spacing the deformation characteristics of the reinforced concrete section can be improved significantly. The basic idea, that concrete can undergo large strains in the neighborhood of the reinforcement and the magnitude of the strains depends on the distribution and subdivision of the reinforcement throughout the mass of the concrete, led to the evolution of new versatile form of reinforced concrete called 'ferrocement'.

\subsection{Two Phase Material}

The structural behavior of ferrocement is different from conventional reinforced concrete. The dispersion of small diameter steel wires closely and uniformly in the entire volume of the ferrocement element improves many engineering properties like impact resistance, fatigue resistance, tensile strength, toughness and flexural strength. In ferrocement, there is a combined action of steel and mortar in tension zone even after cracking. Thereby, the tensile strength of mortar is improved due to close spacing of wires. The presence of steel phase improves the deformation characteristics of other phase i.e. mortar. Thus, ferrocement is defined as a two phase composite material, the steel phase acting as the reinforcement phase and mortar phase as the matrix.

\subsection{Definition}

American concrete institute committee defines ferrocement as "a type of thin wall reinforced concrete construction where in usually hydraulic cement is reinforced with layers of continuous and relatively small diameter mesh. The mesh may be made of metallic material or other suitable material."

\subsection{Technology}

Ferrocement construction requires less skilled personnel and can be constructed on self-help basis. Hence it has gained popularity throughout the world. The wire meshes are usually 
$0.5 \mathrm{~mm}$ t0 $1 \mathrm{~mm}$ in diameter and spaced at $5 \mathrm{~mm}$ to $25 \mathrm{~mm}$ apart and volume of mesh ranges $1 \%$ to $8 \%$ of the total volume of the structural element. The thickness of ferrocement section varies from $10 \mathrm{~mm}$ to $40 \mathrm{~mm}$. The cover to the outermost layer of wires is usually $1.5 \mathrm{~mm} \mathrm{t0} 2 \mathrm{~mm}$. The cement mortar consists of ordinary Portland cement, water and fine aggregate , generally below $5 \mathrm{~mm}$ to $7 \mathrm{~mm}$ in size is often around $2 \mathrm{~mm}$ in order to permit a more closely spaced mesh.

\subsection{Cracking}

Mechanism of crack formation in ferrocement can be explained in a way similar to the explanation given in the case of reinforced concrete, namely that based on bond-slip hypothesis. When a feroocement element is subjected to uniaxial tension, primary cracks form at random critical sectionswhere the tensile stress in the mortar exceeds the tensile strength. At these cracks, bond is broken, a slip occurs between wires and mortar and all the load is taken by wires only. In between these cracks, tensile stresses exist in the mortar and as it stresses along the fibers, bond stresses are also present. With the increase of the further load, sections, which carry highest tensile strength, crack, when the stresses exceed the tensile strength of the mortar and thus, new cracks are formed. This process continues till the spacing of the cracks becomes sufficiently small, so that the maximum tensile stresses in the mortar between the already formed cracks are just equal to or less than the tensile strength. At this stage, the number of cracks that formed have stabilized, no more new cracks form with further increase of load and spacing of cracks has reached its smallest value possible.

\subsection{Applications}

The confidence in the behavior of the material has increased with wide range of applications. Though the material properties are not fully investigated, its applications are increasing to a great extent. Many marine structures were constructed with ferrocement and it is finding place in terrestrial structures also in recent years. Ferrocement initially gained popularity with the construction of small boats. Almost during the same period corrugated sheets made of ferrocement were used as roof element in place of conventional asbestos sheet in Sri-Lanka which are $25 \%$ economical that the conventional one. Also it facilitates repair of damaged zones simply by plastering. It is also used for complex curve units, curved panels, shells or domes, septic tanks, tanks for stirage of water, oil or grains, fishing boats, small vessels, roof or wall panels for low cost housing, bio-gas holders ,sewersand pipes etc.

It is thus seen that, on account of favorable properties of ferrocement number of interesting fields of application have been opened up, where strength, durability, water tightness , ductility and economy are of prime importance.

\section{FLEXURAL BEHAVIOR OF FERROCEMENT SLAB UNDER GRADUAL LOADING}

The flexural behavior of ferrocement, due to its composite nature, is different from that of reinforced concrete. Analytical methods were attempted to estimate the moment carrying capacity of ferrocement in flexure based on the experimental investigations.

The general conclusion of various authors $1,2,3,4$ is that the crack spacing decreased with increase in specific surface of reinforcement. Surya kumar et al.6reported that ultimate strength and strength at first crack varied linearly with percentage of reinforcement.Desaiy2reported that mesh mortal parameter influences the flexural strength of the ferrocement. Logen and shah reported that moment at first crack varied linearly with specific surface of the reinforcement. All these investigators had adopted reinforced concrete theory for analysis of ferrocement in flexure. The value of moment of resistance, calculated by reinforced concrete theory, usually underestimated the experimental moment. Balguru 1 conducted experimental and analytical investigations on ferrocement slabs. The basic mechanism of flexure of mortar and concrete under load is the initiation and propagation of small cracks and flaws, which extend and interconnect until the whole internal structure, was completely disputed. Suryakumar6 reported that the modulus of elasticity in bending increased linearly with increase in steel content. Also, they reported that ferrocement with conventional reinforcement along with meshes exhibits superior strength and deformability characteristics. Welded wire mesh is superior from strength point of view compared to other meshes. Basubal reported that the presence of continuous wire mesh reinforcement sharply increased the load capacity of the panel and improved ductility. Trikha studied the orientation and effect of arrangement of hexagonal mesh on the behavior of two way ferrocement slab to determine most efficient arrangement of mesh layers for ferrocement composites. As a result, he stated that arrangement consisting of twin layers with two meshes orthogonally oriented and placed in contact is superior to the other two arrangements consisting of unidirectional oriented or alternate layers equally spaced with orthogonal oriented meshes. Kotadwala reported that the hexagonal meshes were found less efficient as compared to square meshes for constant mesh-mortar parameters. Kaushik reported that size and specific surface of mesh reinforcement significantly affect the average crack spacing at ultimate load.

\section{EXPERIMENTATION}

In this study the attempt is made to cast total twelve number of ferrocement slabs of size $0.9 \mathrm{~m} \times 2 \mathrm{~m}$ having thickness $50 \mathrm{~mm}$. and also two RCC slabs are casted. Both ferrocement and RCC slabs are tested manually by using sand bags to 
overcome the problem of disbelief of people because of which ferrocement did not lead to use in terrestrial structures.

\subsection{General}

The cement sand mortar of mix proportion (1:2) by weight and water cement ratio was kept constant for all tests. Ordinary Portland cement was used as per IS 269- 1976 and clean river sand having fineness modulus 1.52 was used to cast the ferrocement slabs. The three types of welded wire meshes

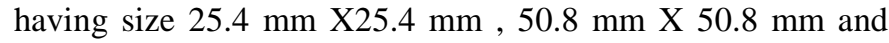
$25.4 \mathrm{~mm}$ X $76.2 \mathrm{~mm}$ were used to cast the ferrocement slabs.

\subsection{Casting}

Ferrocement slab panels were casted on leveled and nonabsorbent floor. To make panels of required dimensions rolled steel angle sections of $50 \mathrm{~mm}$ X $50 \mathrm{~mm} \mathrm{X} 8 \mathrm{~mm}$ were used. For casting of slab panels, the required number of meshes were cut from the bundle and kept ready for use with $6 \mathrm{~mm}$ spacer bars. 1:2 cement sand mortar was then placed in the slab mould up to a depth of approximately $6 \mathrm{~mm}$., which was the required cover to the reinforcement. The first layer of reinforcing mesh was then placed over the compacted mortar and then over this the remaining layers of mesh with spacer bars tied at bottom were placed. The slab mould was filled with mortar to the full depth of $5 \mathrm{~cm}$. the mortar was well compacted by beating it with heavy block and the surface was smoothened by using planes and a long wooden strip. All specimens were moist cured by covering them with wet gunny bags for ten days and later on they were shifted to the curing pond.

\subsection{Testing}

After twenty eight days curing the slab panels were white washed to obtain the clear picture of cracks under different stages of loading. The slab panels were tested under gradual uniformly distributed loading by using sand bags over a simply supported span of $1.8 \mathrm{~m}$. Dial gauges were used to measure the deflections at center and $\mathrm{L} / 6$ from either end. The deflections were measured at an interval of $0,1,3,6,9,12$ and 24 hours after loading. The first load was kept equal to working load designed by limit state method. Every next increment of 50 percent of working load was placed on the slab on next day. The load was applied gradually and for every increment of load the dial gauge readings were recorded. And the cracks were observed with the help of magnifying glass. The first cracking load and ultimate load were recorded. The slab panels were tested till collapse. (photograph- note - The slab panels broken in to two pieces were also used for loading purpose.)

The same procedure was adopted for casting and testing of RCC slab panels.

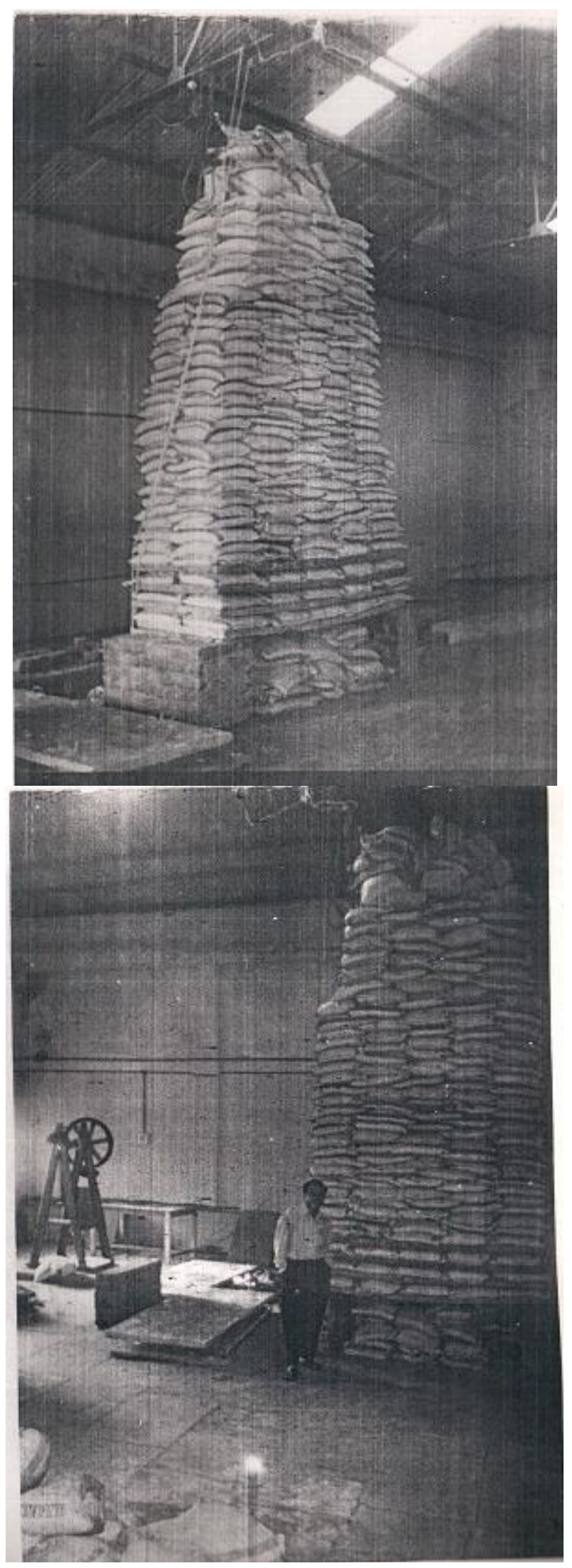




\subsection{Results}

\begin{tabular}{|c|c|c|c|c|c|c|}
\hline \multirow[t]{2}{*}{ Day } & \multirow[t]{2}{*}{$\begin{array}{l}\text { Loa } \\
\mathrm{d} \\
(\mathrm{N} \\
\text { ) }\end{array}$} & \multirow[t]{2}{*}{$\begin{array}{l}\text { Hou } \\
\text { rs }\end{array}$} & $\begin{array}{l}\text { Average } \\
\text { deflectio } \\
\mathrm{n} \text { at } \mathrm{L} / 3 \\
(\mathrm{~mm})\end{array}$ & $\begin{array}{l}\text { Avera } \\
\text { ge } \\
\text { deflect } \\
\text { ion at } \\
\mathrm{L} / 3 \\
\mathrm{~mm})\end{array}$ & $\begin{array}{l}\text { Average } \\
\text { deflectio } \\
\mathrm{n} \text { at } \mathrm{L} / 2 \\
(\mathrm{~mm})\end{array}$ & $\begin{array}{l}\text { Avera } \\
\text { ge } \\
\text { deflect } \\
\text { ion at } \\
\mathrm{L} / 2 \\
\mathrm{~mm})\end{array}$ \\
\hline & & & $\begin{array}{l}\text { ferroce } \\
\text { ment }\end{array}$ & RCC & $\begin{array}{l}\text { ferroce } \\
\text { ment }\end{array}$ & RCC \\
\hline \multirow[t]{7}{*}{ First } & \multirow{7}{*}{$\begin{array}{l}400 \\
0\end{array}$} & 0 & 0.840 & 1.388 & 0.960 & 1.420 \\
\hline & & 1 & 1.007 & 1.565 & 1.105 & 1.590 \\
\hline & & 3 & 1.038 & 1.620 & 1.140 & 1.665 \\
\hline & & 6 & 1.053 & 1.675 & 1.160 & 1.725 \\
\hline & & 9 & 1.065 & 1.705 & 1.170 & 1.765 \\
\hline & & 12 & 1.098 & 1.725 & 1.185 & 1.795 \\
\hline & & 24 & 1.100 & 1.810 & 1.260 & 1.910 \\
\hline \multirow{7}{*}{$\begin{array}{l}\text { Seco } \\
\text { nd }\end{array}$} & \multirow{7}{*}{$\begin{array}{l}600 \\
0\end{array}$} & 0 & 1.445 & 2.553 & 1.760 & 2.730 \\
\hline & & 1 & 1.633 & 2.745 & 1.965 & 2.940 \\
\hline & & 3 & 1.755 & 2.938 & 2.170 & 3.160 \\
\hline & & 6 & 1.828 & 3.010 & 2.250 & 3.230 \\
\hline & & 9 & 1.880 & 3.110 & 2.340 & 3.325 \\
\hline & & 12 & 1.940 & 3.150 & 2.410 & 3.385 \\
\hline & & 24 & 2.203 & 3.388 & 2.695 & 3.625 \\
\hline \multirow{7}{*}{$\begin{array}{l}\text { Thir } \\
\text { d }\end{array}$} & \multirow{7}{*}{$\begin{array}{l}800 \\
0\end{array}$} & 0 & 2.640 & 3.965 & 3.225 & 4.155 \\
\hline & & 1 & 2.800 & 4.245 & 3.425 & 4.425 \\
\hline & & 3 & 2.883 & 4.423 & 3.540 & 4.610 \\
\hline & & 6 & 2.980 & 4.550 & 3.645 & 4.735 \\
\hline & & 9 & 3.073 & 4.623 & 3.750 & 4.900 \\
\hline & & 12 & 3.148 & 4.730 & 3.840 & 4.995 \\
\hline & & 24 & 3.355 & 4.780 & 4.105 & 5.305 \\
\hline \multirow{7}{*}{$\begin{array}{l}\text { Four } \\
\text { th }\end{array}$} & \multirow{7}{*}{$\begin{array}{l}100 \\
00\end{array}$} & 0 & 3.803 & 5.425 & 4.660 & 6.455 \\
\hline & & 1 & 4063 & 5.635 & 4.980 & 6.855 \\
\hline & & 3 & 4.128 & 5.815 & 5.050 & 7.095 \\
\hline & & 6 & 4275 & 5.943 & 5.250 & 7.225 \\
\hline & & 9 & 4.368 & 6.000 & 5.350 & 7.300 \\
\hline & & 12 & 4.418 & 6.200 & 5.400 & 7.425 \\
\hline & & 24 & 4.663 & 6.335 & 5.695 & 7.660 \\
\hline \multirow[t]{7}{*}{ Fifth } & \multirow{7}{*}{$\begin{array}{l}120 \\
00\end{array}$} & 0 & 4.513 & 6.525 & 6.375 & 8.825 \\
\hline & & 1 & 5.550 & 6.225 & 6.775 & 9.325 \\
\hline & & 3 & 5.723 & 6.460 & 7.010 & 9.565 \\
\hline & & 6 & 5.873 & 6.380 & 7.145 & 9.085 \\
\hline & & 9 & 5.895 & 6.445 & 7.215 & 9.990 \\
\hline & & 12 & 6.105 & 7.835 & 7.315 & 10.035 \\
\hline & & 24 & 6.230 & 7.990 & 7.570 & 10.225 \\
\hline \multirow[t]{7}{*}{ Sixth } & \multirow{7}{*}{$\begin{array}{l}140 \\
00\end{array}$} & 0 & 6.793 & 9.227 & 8.285 & 11.300 \\
\hline & & 1 & 7.098 & 9.580 & 8.650 & 11.620 \\
\hline & & 3 & 7.243 & 9.785 & 8.825 & 11.800 \\
\hline & & 6 & 7.310 & 9.855 & 8.915 & 11.860 \\
\hline & & 9 & 7.355 & 9.905 & 8.975 & 11.910 \\
\hline & & 12 & 7.415 & 9.950 & 9.045 & 11.960 \\
\hline & & 24 & 7.638 & 10505 & 9.220 & 12.070 \\
\hline
\end{tabular}

\begin{tabular}{|c|c|c|c|c|c|c|}
\hline \multirow[t]{2}{*}{ Day } & \multirow[t]{2}{*}{$\begin{array}{l}\text { Loa } \\
\text { d } \\
(\mathrm{N} \\
\text { ) }\end{array}$} & \multirow[t]{2}{*}{$\begin{array}{l}\text { Hou } \\
\text { rs }\end{array}$} & $\begin{array}{l}\text { Average } \\
\text { deflecti } \\
\text { on at } \\
\mathrm{L} / 3 \\
(\mathrm{~mm})\end{array}$ & $\begin{array}{l}\text { Avera } \\
\text { ge } \\
\text { deflect } \\
\text { ion at } \\
\mathrm{L} / 3 \quad( \\
\mathrm{mm})\end{array}$ & $\begin{array}{l}\text { Average } \\
\text { deflecti } \\
\text { on at } \\
\mathrm{L} / 2 \\
\mathrm{~mm})\end{array}$ & $\begin{array}{l}\text { Avera } \\
\text { ge } \\
\text { deflect } \\
\text { ion at } \\
\mathrm{L} / 2 \quad( \\
\mathrm{mm})\end{array}$ \\
\hline & & & $\begin{array}{l}\text { ferroce } \\
\text { ment }\end{array}$ & RCC & $\begin{array}{l}\text { ferroce } \\
\text { ment }\end{array}$ & $\mathrm{RCC}$ \\
\hline \multirow{7}{*}{$\begin{array}{l}\text { Seven } \\
\text { th }\end{array}$} & \multirow{7}{*}{$\begin{array}{l}160 \\
00\end{array}$} & 0 & 8.350 & 12.025 & 10.080 & 14.030 \\
\hline & & 1 & 8.548 & 12.435 & 10.420 & 14.440 \\
\hline & & 3 & 8.688 & 12.585 & 10.880 & 14.600 \\
\hline & & 6 & 8.815 & 12.715 & 10.720 & 14.720 \\
\hline & & 9 & 8.895 & 12.780 & 10.815 & 14.790 \\
\hline & & 12 & 8.918 & 12.600 & 10870 & 14.800 \\
\hline & & 24 & 9.110 & 12.715 & 11.100 & 14.920 \\
\hline \multirow[t]{7}{*}{ Eighth } & \multirow{7}{*}{$\begin{array}{l}180 \\
00\end{array}$} & 0 & 9.743 & 14.300 & 11.880 & 16.700 \\
\hline & & 1 & 10.130 & 14.660 & 12.295 & 17.160 \\
\hline & & 3 & 10.218 & 14.685 & 12.460 & 17.350 \\
\hline & & 6 & 10.338 & 14.900 & 12.580 & 17460 \\
\hline & & 9 & 10.398 & 14.950 & 12.610 & 17.550 \\
\hline & & 12 & 10.453 & 14.990 & 12.715 & 17.660 \\
\hline & & 24 & 10.545 & 15.420 & 12.820 & 17.790 \\
\hline \multirow[t]{7}{*}{ Ninth } & \multirow{7}{*}{$\begin{array}{l}200 \\
00\end{array}$} & 0 & 11.220 & 15.850 & 13650 & 18.000 \\
\hline & & 1 & 11.460 & 16.050 & 13.950 & 18400 \\
\hline & & 3 & 11.550 & 16.100 & 14.050 & 18.600 \\
\hline & & 6 & 11.620 & 16.215 & 14.030 & 18.720 \\
\hline & & 9 & 11.660 & 16.285 & 14.205 & 18.790 \\
\hline & & 12 & 11.700 & 16.340 & 14.260 & 18.845 \\
\hline & & 24 & 11.830 & 16.330 & 14.400 & 18.920 \\
\hline \multirow[t]{7}{*}{ Tenth } & \multirow{7}{*}{$\begin{array}{l}220 \\
00\end{array}$} & 0 & 12.655 & 18.050 & 15.390 & 21.070 \\
\hline & & 1 & 12.833 & 18.360 & 15.615 & 21.460 \\
\hline & & 3 & 12.995 & 18.450 & 15.700 & 21.550 \\
\hline & & 6 & 12968 & 18.885 & 15.750 & 21.970 \\
\hline & & 9 & 13.008 & 18.990 & 15.800 & 22.155 \\
\hline & & 12 & 13.045 & 19.050 & 15.840 & 22.600 \\
\hline & & 24 & 13.628 & 19.285 & 16.050 & 22.890 \\
\hline \multirow{7}{*}{$\begin{array}{l}\text { Eleve } \\
\text { nth }\end{array}$} & \multirow{7}{*}{$\begin{array}{l}240 \\
00\end{array}$} & 0 & 14.138 & & 17.190 & \\
\hline & & 1 & 14.218 & & 17.240 & \\
\hline & & 3 & 14.258 & & 17.290 & \\
\hline & & 6 & 14.283 & & 17.330 & \\
\hline & & 9 & 14.293 & & 17.340 & \\
\hline & & 12 & 14.303 & & 17.350 & \\
\hline & & 24 & 14.410 & & 17.465 & \\
\hline \multirow{7}{*}{$\begin{array}{l}\text { Twelv } \\
\text { eth }\end{array}$} & \multirow{7}{*}{$\begin{array}{l}260 \\
00\end{array}$} & 0 & 15.265 & & 18.455 & \\
\hline & & 1 & 15.355 & & 18.575 & \\
\hline & & 3 & 15.388 & & 18.645 & \\
\hline & & 6 & 15.428 & & 18.695 & \\
\hline & & 9 & 15.468 & & 18.735 & \\
\hline & & 12 & 15.503 & & 18.775 & \\
\hline & & 24 & 15.565 & & 18.855 & \\
\hline
\end{tabular}




\begin{tabular}{|c|c|c|c|c|c|c|}
\hline \multirow[t]{2}{*}{ Day } & \multirow[t]{2}{*}{$\begin{array}{l}\text { Loa } \\
\text { d } \\
(\mathrm{N} \\
\text { ) }\end{array}$} & \multirow[t]{2}{*}{$\begin{array}{l}\text { Ho } \\
\text { urs }\end{array}$} & $\begin{array}{l}\text { Averag } \\
\text { e } \\
\text { deflecti } \\
\text { on at } \\
\mathrm{L} / 3 \\
(\mathrm{~mm})\end{array}$ & $\begin{array}{l}\text { Avera } \\
\text { ge } \\
\text { deflec } \\
\text { tion at } \\
\mathrm{L} / 3 \quad( \\
\mathrm{mm})\end{array}$ & $\begin{array}{l}\text { Averag } \\
\text { e } \\
\text { deflecti } \\
\text { on at } \\
\mathrm{L} / 2 \quad( \\
\mathrm{mm})\end{array}$ & $\begin{array}{l}\text { Avera } \\
\text { ge } \\
\text { deflec } \\
\text { tion at } \\
\mathrm{L} / 2 \quad( \\
\mathrm{mm})\end{array}$ \\
\hline & & & $\begin{array}{l}\text { ferroce } \\
\text { ment }\end{array}$ & RCC & $\begin{array}{l}\text { ferroce } \\
\text { ment }\end{array}$ & $\mathrm{RCC}$ \\
\hline \multirow{7}{*}{$\begin{array}{l}\text { Thirtee } \\
\text { nth }\end{array}$} & \multirow{7}{*}{$\begin{array}{l}280 \\
00\end{array}$} & 0 & 17.133 & & 20.725 & \\
\hline & & 1 & 17.263 & & 20.865 & \\
\hline & & 3 & 17.370 & & 20.975 & \\
\hline & & 6 & 17.410 & & 21.025 & \\
\hline & & 9 & 17.448 & & 21.075 & \\
\hline & & 12 & 17.478 & & 21.115 & \\
\hline & & 24 & 17.615 & & 21.255 & \\
\hline \multirow{7}{*}{$\begin{array}{l}\text { Fourtee } \\
\text { nth }\end{array}$} & \multirow{7}{*}{$\begin{array}{l}300 \\
00\end{array}$} & 0 & 18.928 & & 22.780 & \\
\hline & & 1 & 18.970 & & 22.830 & \\
\hline & & 3 & 19.000 & & 22.860 & \\
\hline & & 6 & 19.123 & & 22.880 & \\
\hline & & 9 & 19.025 & & 22.890 & \\
\hline & & 12 & 19.035 & & 22.895 & \\
\hline & & 24 & 19.153 & & 22.980 & \\
\hline \multirow{7}{*}{$\begin{array}{l}\text { Fifteent } \\
\text { h }\end{array}$} & \multirow{7}{*}{$\begin{array}{l}400 \\
00\end{array}$} & 0 & 21.453 & & 25.06 & \\
\hline & & 1 & 21.573 & & 25.685 & \\
\hline & & 3 & 21.643 & & 25.765 & \\
\hline & & 6 & 21.733 & & 25.850 & \\
\hline & & 9 & 21.805 & & 25.940 & \\
\hline & & 12 & 21.873 & & 26.005 & \\
\hline & & 24 & 21.968 & & 26.105 & \\
\hline \multirow{7}{*}{$\begin{array}{l}\text { Sixteent } \\
\text { h }\end{array}$} & \multirow{7}{*}{$\begin{array}{l}440 \\
00\end{array}$} & 0 & 22.638 & & 26.975 & \\
\hline & & 1 & 22.740 & & 27.070 & \\
\hline & & 3 & 22.800 & & 27.130 & \\
\hline & & 6 & 22.845 & & 27.615 & \\
\hline & & 9 & 22.890 & & 27.235 & \\
\hline & & 12 & 22.960 & & 27.335 & \\
\hline & & 24 & 23.035 & & 27.410 & \\
\hline \multirow{7}{*}{$\begin{array}{l}\text { Sevente } \\
\text { enth }\end{array}$} & \multirow{7}{*}{$\begin{array}{l}460 \\
00\end{array}$} & 0 & 24.230 & & 29.100 & \\
\hline & & 1 & 24.470 & & 29.950 & \\
\hline & & 3 & 24.520 & & 29.310 & \\
\hline & & 6 & 24.560 & & 29.360 & \\
\hline & & 9 & 24.570 & & 29.370 & \\
\hline & & 12 & 24.650 & & 29.400 & \\
\hline & & 24 & 24.775 & & 29.470 & \\
\hline \multirow{7}{*}{$\begin{array}{l}\text { Eightee } \\
\text { nth }\end{array}$} & \multirow{7}{*}{$\begin{array}{l}480 \\
00\end{array}$} & 0 & 25.910 & & 31.020 & \\
\hline & & 1 & 25.935 & & 31.050 & \\
\hline & & 3 & 25.965 & & 31.090 & \\
\hline & & 6 & 26.045 & & 31.210 & \\
\hline & & 9 & 26.065 & & 31.250 & \\
\hline & & 12 & 26.105 & & 31.290 & \\
\hline & & 24 & 26.225 & & 31.420 & \\
\hline
\end{tabular}

\section{DISCUSSION AND CONCLUSIONS}

The cracking load strongly depends on the specific surface of the reinforcement, volume of fraction. The square meshes found superior than the rectangular meshes having same percentage of reinforcement along the longitudinal direction or span direction. The first cracking load also depends on the percentage of reinforcement in perpendicular to span direction.

A very large number of fine and narrowly and uniformly spaced cracks were observed in ferrocement slabs, whereas the numbers of cracks observed in RCC slabs are less but the width if cracks were wide as compared to ferrocement slab. In ferrocement cracks showed the tendency to close after the load was removed. Also, even at failure load, closing of cracks and recovery of deflection were noticed in case of ferrocement slabs. Thus wire meshes acted as crack arrestors and also introduced ductility in slab panel.

In order to compare the test results with theoretical results , ultimate load was calculated by using the method developed by Hogenstad. And limit state method.

When the test results of ferrocement were compared it was found that the first cracking load of ferrocement was more by 1.7 times than the RCC slab.

Load corresponding to the deflection of span/250 in ferrocement slab is 1.2 times more than RCC slab.

The behavior of ferrocement slab was observed more ductile and elastic as compared to RCC slab.

The efficiency ratio of ferrocement slab was more by 2.36 and 1.221 times at first cracking and at collapse respectively.

The deflections were observed in RCC slab panels are more by $18.6 \%$ than the ferrocement slab. Also the creep observed in RCC slab was more than the ferrocement slab.

\section{REFERENCES}

[1] Balaguru P. N., " analysis and behavior of ferrocement in flexure", Journal of Structural Engineering Division ASCE, Vol. 103, ST 10 October 1977, pp 1937-1951.

[2] Desayi P and Jacob A. K., "Strength and behavior of ferrocement in tension and flexure", Proceedings of (Vol.1) of the Symposium on modern trends in Civil Engineering, University of Roorkee, Nov.,1972, pp 274- 279.

[3] D. N. Trikhs, S. K. Kaushik and R. R. Kotdawala, “ Limit analysis of ferrocement thin slabs", Journal of ferrocement Vol. II No. 2, April 1981, pp 111-124.

[4] R. N. Swamy and A Spanos, " Creep behavior of ferrocement sections", Journal of ferrocement Vol. 15 No 2. July 1985, pp 117-129. 
[5] Suryakumar G. V. Sharma P. C., “ An investigation of the ultimate and first crack strengths of ferrocement in flexure", Indian Concrete Journal, Nov. 1976, pp 335340 .

[6] W. N. Al. Rifale and D. N. Trikha, “ Effect of arrangement and orientation of hexagonal mesh on behavior of two way ferrocement slabs", Journal of Ferrocement Vol. 20 No3, July1990,pp219-229

[7] S. S. Dharane, " Behavior of ferrocement slab under gradual and cyclic loading",M. E. Dissertation submitted to Shivaji University, Kolhapur (India).

\section{BIOGRAPHIES}

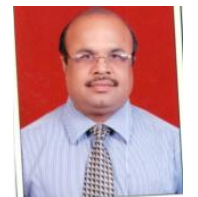

Sidramappa Shivashankar Dharane received the B.E. Civil and M.E. Civil -Structures degrees from Marathawada University, Aurangabad (India) and Shivaji University, Kolhapur (India) in 1992 and 1999, respectively. At present working as a Assistant Professor in Civil Engineering department at SVERI's College of Engineering Pandharpur (India). Also working as a recognized post graduate teacher for M.E. Civil- Structures course in Solapur University ,India

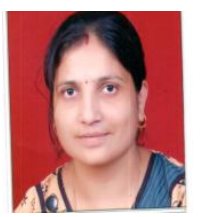

Archita Vijaykumar Malge received B. Sc. , M. Sc. And B. Ed. Degrees from Dr. Babasaheb Ambedkar Marathawada University, Aurangabad (India) in 2000 and 2006 , respectively. At present working as a Assistant Professor in Mathematics department at SVERI's College of Engineering Pandharpur (India). 